ORIGINAL ARTICLE

\title{
Immunogenicity of routine vaccination against diphtheria, tetanus, and Haemophilus influenzae type b in Asian infants born in the United Kingdom
}

\author{
R Booy, E A Haworth, K A Ali, H M Chapel, E R Moxon
}

Arch Dis Child 2005;90:589-591. doi: 10.1136/adc.2004.064469

See end of article for authors' affiliations

Correspondence to:

Professor Robert Booy Research Centre for Child Health, 1 st Floor Luckes House, Royal London Hospital, Stepney Way, London EI IBB, UK; r.booy@qmul.ac.uk

Accepted 18 January 2005

\begin{abstract}
Aim: To determine the immunogenicity of routine vaccination against diphtheria, tetanus, and Haemophilus influenzae type $b$ (Hib) in Asian infants born in the UK, and whether maternal antibody suppression occurs.

Methods: A cohort study with $80 \%$ power, within $95 \%$ confidence limits, to show that $80 \%$ or fewer Asian infants would respond with an anti-PRP antibody concentration $>0.15 \mu \mathrm{g} / \mathrm{ml}$. Infants of South Asian origin born in Berkshire were enrolled at two general practices in Reading: 41 Asian families sequentially asked to participate within 2 weeks of birth; 36 infants were enrolled and 34 completed the study. Main outcome measures were: antibody concentration against diphtheria, tetanus, and Hib expressed as geometric mean titres (GMT) and proportion of infants about a threshold protective antibody concentration.

Results: Median age for completing primary vaccination course was 5 months. All 34 achieved anti-PRP antibody concentration of $>0.15 \mu \mathrm{g} / \mathrm{ml}, 33$ were $>1.0 \mu \mathrm{g} / \mathrm{ml}$, and the GMT was $15.0 \mu \mathrm{g} / \mathrm{ml}$. All infants developed protective antibody concentration $>0.1 \mathrm{IU} / \mathrm{ml}$ for tetanus and diphtheria; the respective GMTs were 1.94 and $5.57 \mathrm{IU} / \mathrm{ml}$. Infants with high $(>0.25 \mathrm{IU} / \mathrm{ml}$ ) antibody concentrations against diphtheria and tetanus at 2 months achieved lower antibody concentrations after their three dose course than those with low concentrations $(<0.1 \mathrm{IU} / \mathrm{ml})(p=0.06$ and 0.03 , respectively).

Conclusions: Despite evidence for maternal antibody suppression of the response to tetanus and diphtheria vaccination, excellent antibody responses were achieved by routine vaccination according to the accelerated schedule. High vaccine coverage should be encouraged to provide protection against the possibility of imported infection.
\end{abstract}

nfections with Haemophilus influenzae type b (Hib), a leading bacterial pathogen of early childhood, can be prevented by routine immunisation. ${ }^{1}$ The incidence of disease may be an order of magnitude higher in developing than in developed countries. ${ }^{2}$ The reasons for this are unclear. Studies have shown higher rates of $H$ influenzae meningitis in Asians than in whites living in the north east Thames region of England $^{3}$ and in blacks compared with whites in an American urban setting. ${ }^{4}$ To ascertain whether the Hib conjugate vaccine, PRP-T (polyribosylribitol phosphate covalently linked to tetanus toxoid, Act-HIB, Aventis Pasteur), was likely to protect Asian infants living in the United Kingdom against invasive infections, we conducted a phase 2 study of vaccination at 2, 3, and 4 months of age among a south Asian (Indian and Pakistani) population where most parents had been born overseas.

We assessed the effect of maternal antibodies on the immune response to diphtheria and tetanus vaccines. Higher rates of natural immunity to diphtheria are likely to have been acquired by mothers who spent their childhood in Asia. Therefore a lesser response to accelerated immunisation (at 2, 3 , and 4 months of age) would be of potential concern, ${ }^{5}$ particularly in Asian children, as their families may be visited by overseas relatives who could introduce toxigenic strains of Corynebacterium diphtheriae. ${ }^{6}$ In the United Kingdom, infants are not given diphtheria booster vaccination in the second year of life, as is a customary elsewhere in developed countries, and so should immunity wane before pre-school boosting, cases of diphtheria could occur in ethnic groups such as Asians.

\section{METHODS}

Following approval by the local ethics committee, two West Berkshire general practices, serving a predominantly Asian population, agreed to participate in this immunogenicity study. Forty one consecutive Asian families were seen by a local health visitor within two weeks of delivery and given both a verbal explanation of the study and a written invitation to participate (translated into five major Asian languages-Gujerati, Hindu, Bengali, Punjabi, and Urdu). When the infant was aged 4 to 6 weeks, each family was telephoned or visited at home by a female Asian research assistant, proficient in Asian languages, who explained the study. Formal written consent was not obtained until the child was brought for the first primary vaccination to the GP's surgery. Details of the ethnic background, consanguinity, and feeding practices were obtained. Venepuncture was carried out before vaccination. All vaccines used were standard issue, so there was a variety of batch numbers. They were not specifically supplied for the study by a pharmaceutical company. PRP-T and diphtheria, tetanus and pertussis (DPT) vaccine were given concurrently but separately by intramuscular injection, according to the accelerated 2, 3, and 4 month regimen. Parents were sent postcard reminders of appointments, in accord with the usual UK practices. One month after completion of the primary series of three immunisations, families were visited by the research doctor $(\mathrm{RB})$ and the Asian research assistant. Details

Abbreviations: GMT, geometric mean titre; Hib, Haemophilus influenzae type b; PRP, polyribosylribitol phosphate 
of any vaccine reactions were obtained and, following the application of EMLA anaesthetic cream, venepuncture was carried out. The concentrations of the IgG antibody to polyribosylribitol phosphate (PRP) and to diphtheria and tetanus toxoids were measured by enzyme linked immunosorbent assay (ELISA), as previously described. ${ }^{57}$

\section{Statistics}

Statistical analyses were carried out using Epinfo version 5; analysis of variance was done on log transformed data and the Kruskal-Wallis test was employed for the non-parametric data. Power calculations were carried out using for comparison a white cohort of 104 Oxfordshire children vaccinated with PRP-T in which $98 \%$ achieved an anti-PRP concentration $>0.15 \mu \mathrm{g} / \mathrm{ml}$ after primary immunisation. ${ }^{7}$ In order for the study to have $80 \%$ power, within $95 \%$ confidence limits, to show that $80 \%$ or less of Asian infants would respond with an anti-PRP antibody concentration of $>0.15 \mu \mathrm{g} / \mathrm{ml}$, a minimum of 32 children was required.

\section{RESULTS}

Thirty six of 41 families agreed to participate. The only reason for refusal was concern about venepuncture. Thirty four families completed the study; two dropped out because they moved away.

All vaccinations were well tolerated and there were no serious reactions. Fever was reported after $30 \%$ of vaccinations and irritability after $17 \%$. Local reactions were more common after the DPT immunisation $(6 \%, 6 \%$, and $12 \%$ after the first, second, and third injections) compared with PRP-T $(3 \%, 6 \%$, and $6 \%)$.

Sufficient blood for analysis was obtained from 28 infants before vaccination and 34 after the three dose series. The median age for starting vaccination was 10 weeks and 4 days and the median age at the third dose was 5 months. The geometric mean titre (GMT) of anti-PRP antibody rose from $0.35 \mu \mathrm{g} / \mathrm{ml}$ preimmunisation to $15.0 \mu \mathrm{g} / \mathrm{ml}$ (95\% confidence interval (CI), 14.0 to 16.0) at completion. All infants developed an antibody concentration of more than $0.15 \mu \mathrm{g} /$ $\mathrm{ml}$, and $97 \%$ (33 of 34) achieved concentrations in excess of $1 \mu \mathrm{g} / \mathrm{ml}$. In one, the product of a consanguineous union, the level was $0.5 \mathrm{mg} / \mathrm{ml}$. The parents of 14 infants were cousins; antibody concentrations achieved in these children were not different from the rest (GMT, $15.5 \vee 14.7 \mu \mathrm{g} / \mathrm{ml}$ ).

Most parents (27 of 36) were from the Punjab, a region that encompasses parts of India and Pakistan. Two sets of parents were from Kashmir, which straddles both countries. Two families were from elsewhere in Pakistan and four from Rajistan in India. The origin of one family was not recorded. Thirty three of 35 fathers and 29 of 35 mothers were born overseas. There was no difference in the response to PRP-T of infants with Punjabi background compared with the other eight children (GMT, $15.4 v 13.8 \mu \mathrm{g} / \mathrm{ml}$ ), neither was there a difference in the 21 breast fed compared with the 13 bottle fed infants (GMT, $14.1 \vee 16.6 \mu \mathrm{g} / \mathrm{ml})$.

After completing vaccination all infants had antibody concentration in excess of $0.1 \mathrm{IU} / \mathrm{ml}$ against tetanus and diphtheria (respective GMTs, $1.94 \mathrm{IU} / \mathrm{ml}$ and $5.57 \mathrm{IU} / \mathrm{ml}$ ). Twenty one of 28 infants had a more than fourfold increase in antibody concentration against tetanus toxoid; in four the increase was less than fourfold and in three infants the antibody concentrations were lower. There was evidence for maternal antibody suppression of the response to the tetanus and diphtheria toxoid vaccines but not in response to the Hib vaccine. The median anti-tetanus toxoid concentration after three doses was $2.81 \mathrm{IU} / \mathrm{ml}$ (25th to 75 th centiles, 1.59 to $4.49 \mathrm{IU} / \mathrm{ml}$ ) in the 13 infants whose concentration before immunisation was $<0.1 \mathrm{IU} / \mathrm{ml}$, compared with 1.36 (0.71 to 2.23) $\mathrm{IU} / \mathrm{ml}$ in the 10 infants whose concentrations before vaccination was $>0.25 \mathrm{IU} / \mathrm{ml}(\mathrm{p}=0.06)$. The median antidiphtheria toxoid antibody concentration after three doses was 7.31 (5.30 to 12.88 ) IU/ml in 12 infants whose antibody concentration pre-immunisation was $<0.1 \mathrm{IU} / \mathrm{ml}$, compared with 3.57 (2.70 to 3.97 ) IU/ml in the four infants whose concentration before immunisation was $>0.25 \mathrm{IU} / \mathrm{ml}$ $(\mathrm{p}=0.03)$.

All Asian infants had anti-diphtheria toxoid antibody concentration in excess of $0.01 \mathrm{IU} / \mathrm{ml}$ before vaccination, compared with only eight of the 90 white infants in a previous study. ${ }^{7}$

\section{DISCUSSION}

The impressive anti-PRP antibody response by Asian infants to routine Hib vaccination with PRP-T, which this study has demonstrated, indicates that the prevention of Hib meningitis $^{3}$ in a relatively high risk population should be attained by good coverage with Hib vaccine. The GMT achieved was threefold higher than in a similar group of white infants we have studied. ${ }^{7}$ The most important difference from our previous study is that the median age for completing three doses of vaccine in white infants was 4 months compared with 5 months in Asian infants; the higher response in Asians may therefore in part be explained by the greater immunocompetence of older infants.

It should be noted that this study is descriptive and uncontrolled so this limits conclusions regarding whether there truly is an ethnically determined difference in immunogenicity. Furthermore, conclusions regarding immunogenicity to Hib were also drawn by comparison with historically established serological correlates of protection that are now known to have limited predictive value for protection. This also limits the usefulness of the study.

The vaccinations were well tolerated, with no serious reactions reported. All the routine vaccinations given were standard issue, so the results are immediately applicable to clinical practice.

Asian mothers appear to pass on much greater concentrations of anti-diphtheria toxoid serum antibody to their infants, probably resulting from natural exposure to toxigenic strains of Corynebacterium diphtheriae during their own childhood in Asia. However, the four mothers born in the UK, in whose infants antibody concentrations against diphtheria were measured before vaccination, passed on an equivalent amount of antibody as the other 24 mothers (in both groups the GMTs were $0.1 \mathrm{IU} / \mathrm{ml}, \mathrm{p}=1.0$ ). This suggests that these four mothers may have been exposed in the UK to toxigenic Corynebacterium diphtheriae imported by visiting relatives. Asian infants are at greater risk from imported diphtheria, ${ }^{6}$ and infection may also spread in schools. ${ }^{8}$ Thus it is important to pay particular attention to ensuring high rates of vaccination against diphtheria in the population.

Our results suggest that maternal antibody suppresses the response to both diphtheria and tetanus vaccination. However, despite this, the antibody concentrations achieved after three doses of vaccination were in excess of those seen in a comparable white population ${ }^{5}$ (table 1) and well above the protective level of $0.1 \mathrm{IU} / \mathrm{ml}$. However, it should be

\begin{tabular}{|c|c|c|}
\hline & White & Asian \\
\hline $\begin{array}{l}\text { Anti-diphtheria } \\
\text { Anti-tetanus }\end{array}$ & $\begin{array}{l}3.87 \mathrm{IU} / \mathrm{ml} \\
0.70 \mathrm{IU} / \mathrm{ml}\end{array}$ & $\begin{array}{l}5.57 \mathrm{IU} / \mathrm{ml} \\
1.94 \mathrm{IU} / \mathrm{ml}\end{array}$ \\
\hline
\end{tabular}


remembered that, as pointed out above, the comparison with white infants is historical, so caution is required in concluding whether there is an ethnic difference in immunogenicity. The key point is that maternal antibody suppression does not appear to have prevented an adequate response to the three dose schedule.

As Asian infants can be protected by routine vaccination against Hib, tetanus, and diphtheria, high uptake rates should be encouraged. The study was carried out in cooperation with two practices run by Asian GPs and involved the use of an Asian interpreter, as well as written information in Asian languages. More than $80 \%$ of the families invited both participated in and completed the study. Although one UK study in the 1980 found that those originating from "New Commonwealth and Pakistan" had significantly lower diphtheria vaccine uptake, ${ }^{9}$ more recent regionally based studies have found higher rates of vaccine coverage in south Asians compared with their European neighbours, ${ }^{10} 11$ and this provides encouragement that vaccine preventable diseases may not emerge in children of Asian immigrants.

\section{Authors' affiliations}

R Booy, K A Ali, Research Centre for Child Health, Barts and The London School of Medicine and Dentistry, Queen Mary University of London, UK E A Haworth, Health Protection Agency, South East England, Colindale, London NW9, UK

H M Chapel, Department of Immunology, Oxford Raddliffe Hospital, Oxford, UK
E R Moxon, Oxford Vaccine Group, Department of Paediatrics, Oxford Radcliffe Hospital

Competing interests: Prof R Booy has acted as a paid consultant for vaccine companies, for example, Wyeth, Aventis Pasteur, and GSK.

\section{REFERENCES}

1 Booy R, Hodgson S, Carpenter L, et al. Efficacy of Haemophilus influenzae type b conjugate vaccine PRP-T. Lancet 1994;344:362-6.

2 Biilmer HA. World-wide epidemiology of Haemophilus influenzae meningitis; industrialised versus non-industrialized countries. Vaccine 1991;9:S5-9.

3 Urwin G, Yuan MF, Feldman RA. Prospective study of bacterial meningitis in North East Thames region, 1991-3, during introduction of Haemophilus influenzae vaccine. BMJ 1994;309:1412-14.

4 Vadheim CM, Greenberg DP, Bordenave N, et al. Risk factors for invasive Haemophilus influenzae type $b$ in Los Angeles County children 18-60 months of age. Am J Epidemiol 1992;136:221-35.

5 Booy R, Aitken SJ, Taylor S, et al. Immunogenicity of combined diphtheria, tetanus, and pertussis vaccine given at 2,3 , and 4 months versus 3,5 , and 9 months of age. Lancet 1992;339:507-10.

6 Anon. Toxigenic Corynebacterium diphtheriae acquired in England. CDR Weekly 1996;6:231.

7 Booy R, Taylor SA, Dobson SR, et al. Immunogenicity and safety of PRP-T conjugate vaccine given according to the British accelerated immunisation schedule. Arch Dis Child 1992;67:475-8.

8 Bowler ICJ, Mandal BK, Schlecht B, Riordan T. Diphtheria - the continuing hazard. Arch Dis Child 1988;63:194-5.

9 Jarman B, Bosanquet N, Rice $P$, et al. Uptake of immunisation in district health authorities in England. BMJ 1988;296:1775-8.

10 Bhopal RS, Samim AK. Immunization uptake of Glasgow Asian children: paradoxical benefit of communication barriers. Commun Med 1988;10:215-20.

11 Martineau A, White M, Bhopal R. No sex differences in immunisation rates of British south Asian children: the effect of migration? BMJ 1997;314:642-3 